\title{
WHY THE CIVIL WAR STILL MATTERS
}

\section{BY JAMES MCPHERSON}

Even before the many conferences, commemorations, books, and other public events associated with bicentennial of Abraham Lincoln's birth in 2009 and now the current sesquicentennial

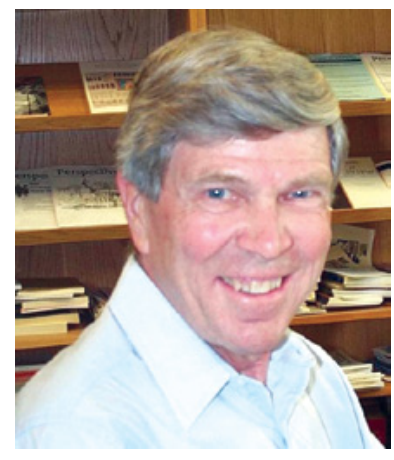

James McPherson observations of the Civil War, the American Civil War was the most popular historical subject in many parts of the United States. Back in the 1980s, the historian at the Vicksburg National Military Park declared "Americans just can't get enough of the Civil War." A bookstore owner in Falls Church, Virginia, said-also in the 1980s-"For the last two years Civil War books have been flying out of here. It's not just the buffs who buy; it's the general public, from high school kids to retired people." Civil War books are the leading sellers for the History Book Club. In 1990 some thirty million viewers watched the Ken Burns eleven hours of television documentary on the Civil War, and re-broadcasts in the past twenty years have lifted the number to at least fifty million in the United States and abroad. Some 40,000 Americans are estimated to be Civil War re-enactors, who re-enact battles every year before thousands of spectators at or near where they took place 150 years ago.

What accounts for this intense interest in the fratricidal conflict that almost tore the country apart, an interest that is even greater now during these years in which we will observe 150th anniversaries of the war's main events? First, perhaps, was the sheer size of the conflict, fought not in some foreign land as most American wars have been, but on battlefields ranging from Pennsylvania to New Mexico and from Florida to Kansas, hallowed ground that Americans can visit today. Then there is the drama and tragedy of the war's human cost-at least 620,000 soldiers

http://dx.doi.org/10.14713/irul.v66i0.1861

Journal of the Rutgers University Libraries, Volume 66, pp.22-33.

JRUL is licensed under a Creative Commons Attribution-

Noncommercial-NoDerivs 3.0 United States License 
plus an unknown number of civilians who lost their lives in the war, recently revised by a demographic historian to an estimated 750,000 . To help you understand the immensity of that figure, it was $2 \%$ or more of the American population in 1860 . If $2 \%$ of Americans were to be killed in a war fought today, the number of American war dead would be more than six million. Or to take another statistic: 23,000 Union and Confederate soldiers were killed, wounded, or missing in a single day at the battle of Antietam on September 17, 1862. This was nearly four times the number of American casualties on another famous single day in American history, D-Day on June 6, 1944. The human cost of the Civil War cast a long shadow forward in our history, and continues to horrify us but also solemnly to impress us 150 years later.

Then there are the larger-than-life, near mythical individuals on both sides whose lives and careers continue to fascinate us today-Abraham Lincoln, Robert E. Lee, Ulysses S. Grant, Stonewall Jackson, William Tecumseh Sherman and Clara Barton-and on and on. There is a kind of romance and glory, as well as tragedy, about these people and their times that is hard to resist.

This drama and romance and tragedy help explain why the Civil War remains such a popular subject, but they don't entirely explain why that war still matters to us today, 150 years later. To start getting at that, I hope you will forgive a little autobiography on my part to account for how and why I became interested in the Civil War, when I was in graduate school, a half century ago-because it was for many of the same reasons why the war still matters to us today, fifty years later.

Unlike many of my friends and colleagues, I did not have a youthful fascination with the Civil War. When I arrived in Baltimore in 1958 for graduate study at Johns Hopkins University, I had not read anything specifically on the subject apart from a couple of books by Bruce Catton. I had not taken a college course on the Civil War because my small college in Minnesota did not offer such a course.

I had a vague and rather naïve interest in the history of the South, in part because, having been born in North Dakota and brought up in Minnesota, I found the South exotic and mysterious. During my senior year in college, nine black students integrated Little Rock Central High School in Arkansas under the protection of the United States Army. I was well enough acquainted with history and current events to know that the constitutional basis for these 
students' presence at Central High was the Fourteenth Amendment, one of the most important products of the Civil War and of the Reconstruction period that followed it. In retrospect, it seems likely that this awareness planted the seeds of my interest in the Civil War era.

That seed germinated within days of my arrival at Johns Hopkins, when like other incoming graduate students, I met with a prospective academic adviser. Mine was Professor C. Vann Woodward, the foremost historian of the American South, whose book The Strange Career of Jim Crow became almost the bible of the civil rights movement. My appointment was postponed for a day because Woodward had been called to Washington to testify before a Congressional committee about potential problems in Little Rock as a second year of school desegregation got under way. Here was a revelation; a historian offering counsel on the most important domestic issue of the day. If I had not seen the connection between the Civil War and my own times before, I certainly discovered it then.

That consciousness grew during my four years in Baltimore. The last two of those years were also the opening phase of the commemoration of the Civil War centennial. But that made little impression on me except for the initial events in Charleston, South Carolina, in April 1961 when a black delegate from New Jersey's centennial commission was denied a room at the Francis Marion Hotel. In protest, several Northern delegations walked out of the events, boycotting them until President John F. Kennedy offered the integrated facilities at the Charleston Naval Base. This offer provoked the Southern delegates to secede from the national commission and hold their own events at the hotel. It all seemed like déjà vu.

Apart from that incident, the civil rights movement eclipsed the centennial observations during the first half of the 1960s. These were the years of sit-ins and freedom rides in the South, of Southern political leaders vowing what they called "massive resistance" to national laws and court decisions, of federal marshals and troops trying to protect civil rights demonstrators, of conflict and violence, of the March on Washington in August 1963, when Martin Luther King Jr. stood before the Lincoln Memorial and began his "I Have a Dream" speech with the words: "Five score years ago, a great American, in whose symbolic shadow we stand today, signed the Emancipation Proclamation. This momentous decree came as a great beacon light of hope to millions of Negro slaves who had 
been scarred in the flame of withering injustice." These were also the years of the Civil Rights Act of 1964 and the Voting Rights Act of 1965, which derived their constitutional basis from the Fourteenth and Fifteenth Amendments adopted a century earlier. The creation of the Freedmen's Bureau by the federal government in 1865 to aid the transition of four million slaves to freedom, was the first largescale intervention by the government in the field of social welfare.

It was the parallels between the 1960s and 1860s, and the roots of events in my own time in events of exactly a century earlier, that propelled me to become a historian of the Civil War and Reconstruction. I became convinced that I could not fully understand the issues and events of my own time unless I learned about their roots in the years of the Civil War: slavery and its abolition; the conflict between the North and South; the struggle between state sovereignty and the federal government; the role of the government in social change and social welfare, and resistance to both government and to social welfare. Those issues are as salient and controversial today as they were in the 1960s, not to mention the 1860s. Today, we have an African American president of the United States, which would not have been possible without the civil rights movement of a half-century ago, which in turn would not have been possible without the events of the Civil War and Reconstruction Era. Many of the issues over which the Civil War was fought still resonate today: matters of race and citizenship; regional rivalries; the relative powers and responsibilities of federal, state, and local governments. The first section of the Fourteenth Amendment, which among other things conferred American citizenship on anyone born in the United States, has become controversial today because of growing concern about illegal immigration. As the great Southern novelist William Faulkner once said: "The past is not dead; it is not even the past."

Let's take a closer look at some of those aspects of the Civil War that are neither dead nor past. At first glance, it appeared that Northern victory in the war resolved two fundamental, festering issues that had been left unresolved by the Revolution of 1776 that had given birth to the nation: first, whether this fragile republican experiment called the United States would survive as one nation, indivisible; and second, whether the house divided would continue to endure half slave and half free. Both of these issues had remained open questions until 1865. Many Americans in the early decades of the country's history were concerned about whether the nation 
would break apart; many European conservatives predicted its demise; some Americans had advocated the right of secession and periodically threatened to invoke it; eleven states did invoke it in 1861. But since 1865 no state or region has seriously threatened secession, not even during the decade of "massive resistance" to desegregation from 1954 to 1964 . When I say seriously, I don't mean to deny that some groups and individuals have indeed threatened secession, but how serious they are is open to question-for example the current governor of Texas, Rick Perry, who has openly asserted his state's right to secede, but somewhat inconsistently ran for the Republican nomination for president of the United States!

By the 1850s the United States, which had been founded on a charter that declared all men created equal with an equal title of liberty, had become the largest slaveholding country in the world, making a mockery of this country's professions of freedom and equal rights. As Abraham Lincoln put it in a speech in 1854, "the monstrous injustice of slavery ... deprives our republican example of its just influence in the world-enables the enemies of free institutions, with plausibility, to taunt us as hypocrites." But with the Emancipation Proclamation in 1863 and the Thirteenth Amendment to the Constitution in 1865, that particular "monstrous injustice" and "hypocrisy" has existed no more. Yet the legacy of slavery in the form of racial discrimination and prejudice long plagued the United States, and has not entirely disappeared a century and a half later.

In the process of preserving the Union of 1776 while purging it of slavery, the Civil War also transformed it. Before 1861, the words "United States" were a plural noun: "the United States have a republican form of government." Since 1865 the United States is a singular noun. The U.S. was a world power. The North went to war to preserve the Union; it ended by creating a nation. This transformation can be traced in Lincoln's most important wartime addresses. His first inaugural address, in 1861, contained the word "Union" twenty times and the word "nation" not once. In Lincoln's first message to Congress, on July 4, 1861, he used the word Union 32 times and nation only three times. In his famous public letter to Horace Greeley of August 22, 1862, concerning slavery and the war, Lincoln spoke of the Union eight times and the nation not at all. But in the brief Gettysburg Address fifteen months later, he did not refer to the Union at all but used the word nation five times. And in 
the second inaugural address, looking back over the trauma of the past four years, Lincoln spoke of one side seeking to dissolve the Union in 1861 and the other side accepting the challenge of war to preserve the nation.

The decentralized antebellum republic, in which the post office was the only agency of national government that touched the average citizen, was transformed by the crucible of war into a centralized polity that taxed people directly and created an internal revenue bureau to collect the taxes, expanded the jurisdiction of federal courts, created a national currency and a federally chartered banking system, drafted men into the army, and created the Freedmen's Bureau as the first national agency for social welfare. Eleven of the first twelve amendments to the Constitution had limited the powers of the national government; most of them contained some form of the words that the federal government "shall not" have certain powers. Most of the next fifteen constitutional amendments, starting with the Thirteenth Amendment in 1865, contain the words that the federal government "shall have the power" to enforce these provisions. The first three of the post-Civil War constitutional amendments transformed four million slaves into citizens and voters with five years, the most rapid and fundamental social transformation in American history-even if the nation did backslide on part of this commitment for three generations after 1877 .

From 1789 to 1861, a Southern slaveholder had been president of the United States two-thirds of those years, and two-thirds of the speakers of the House and presidents pro tem of the Senate had also been Southerners. Twenty of the thirty-five Supreme Court justices during that period had been from slave states, which always had a majority on the Court before 1861. After the Civil War a century passed before another resident of a Southern state was elected president-Lyndon Johnson in 1964. For half of a century after the war only one Southerner served as Speaker of the House and none as president pro tem of the Senate. Only five of the twentysix Supreme Court justices appointed during that half-century were Southerners. The institutions and ideology of a plantation society and a slave system that had dominated half of the country before 1861 and sought to dominate more went down with a great crash in 1865 and were replaced by the institutions and ideology of free-labor entrepreneurial capitalism. For better or for worse, the flames of Civil War forged the framework of modern America. 
That last point requires some elaboration. Before 1865 two distinct socioeconomic and cultural systems competed for dominance within the body politic of the United States. Although in retrospect the triumph of free-labor capitalism seems to have been inevitable, that was by no means clear for most of the antebellum generation. Not only did the institutions and ideology of the rural, agricultural, plantation South based on slave labor dominate the United States government during most of that time, but the territory of the slave states also considerably exceeded that of the free states before 1859 and the Southern drive for further territorial expansion seemed more aggressive than that of the North. Most of the slave states seceded from the United States in 1861 not only because they feared the potential threat to the long-term survival of slavery posed by Lincoln's election, but also because they looked forward to the expansion of a dynamic, independent slaveholding polity into new territory by the acquisition of Cuba and perhaps more of Mexico and Central America. If the Confederacy had prevailed in the 1860s, it is quite possible that the emergence of the United States as the world's leading industrial as well as agricultural producer by the end of the nineteenth century and as the world's most powerful nation in the twentieth century might never have happened. That it did happen is certainly one of the most important legacies of the Civil War-not only for America, but also for the world.

The explosive growth of industrial capitalism in the postCivil War generation was not an unmixed blessing. Labor strife and exploitation of workers became endemic. Violence characterized many strikes and efforts by management to break the strikes. At the same time, the Civil War had left the South impoverished, its agricultural economy in shambles and the freed slaves in a limbo of second-class citizenship after the failure of Reconstruction in the 1870 s to fulfill the promise of civil and political equality embodied in the Fourteenth and Fifteenth Amendments to the Constitution.

Those amendments remained in the Constitution, however, and the legacy of the national unity, a strong national government, and a war for freedom inherited from the triumph of the $1860 \mathrm{~s}$ was revived again in the civil rights movement of the 1960s, which finally began the momentous process of making good on the promises of a century earlier. Even though many white Southerners for generations lamented the cause they had lost in 1865-indeed, mourned the world they had lost, a world they romanticized into 
a vision of moonlight and magnolias-white as well as black Southerners are today probably better off because they lost that war than they would have been if they had won it. Some of them might even admit as much.

No single word better expresses what Americans believe their country has stood for from 1776 right down to the present than the word "liberty." The tragic irony of the Civil War is that both sides professed to fight for the heritage of liberty bequeathed to them by the Founding Fathers. North and South alike in 1861 wrapped themselves in the mantle of 1776. But each side interpreted this heritage in opposite ways-and at first neither side included the slaves in the vision of liberty for which they fought. But the slaves did; and by the time of Lincoln's Gettysburg Address in 1863 the North fought not merely for the liberty bequeathed to them by the Founders but also for "a new birth of freedom." These multiple and varying meanings of liberty, and how they dissolved and reformed in kaleidoscope patterns during the war, provide the central meaning of the war for the American experience.

Southern states invoked the example of their forefathers of 1776, who seceded from the British Empire in the name of liberty to govern themselves. Southern secessionists proclaimed in 1861 that "the same spirit of freedom and independence that impelled our Fathers to the separation from the British government," would impel the "liberty loving people of the South" to separation from the United States. Jefferson Davis declared from "the high and solemn motive of defending and protecting the rights which our fathers bequeathed to us," let us "renew such sacrifices as our fathers made to the holy cause of constitutional liberty."

One of the liberties for which Southern whites contended, Lincoln had said sarcastically back in 1854, was the "liberty to make slaves of other people." In 1861 many Northerners also ridiculed the Confederacy's profession to be fighting for the same ideals of liberty as their forefathers of 1776. That was "a libel upon the whole character and conduct the men of '76," said the antislavery poet and journalist William Cullen Bryant. Ignoring the fact that many of the Founding Fathers owned slaves, Bryant claimed that the Founders fought the revolution "to establish the rights of man... and principles of universal liberty," while the South in 1861 seceded "not in the interest of general humanity, but of a domestic despotism... Their motto is not liberty, but slavery." 
In 1864 Lincoln, as he often did, used a parable to make an important point, in this case a point about the multiple meanings of liberty. He did so in a speech at Baltimore, in a slave state that had remained in the Union and was even then engaged in better debates about a state constitutional to abolish slavery in Maryland (which narrowly passed later that year, by the way). "The world has never had a good definition of the word liberty, and the American people, just now, are much in want of one," said Lincoln on this occasion. "We all declare for liberty; but in using the same word we do not all mean the same thing. With some the word liberty may mean for each man to do as he pleases with himself, and the product of his labor; while with others the same word may mean for some men to do as they please with other men, and the product of other men's labor. Here are two, not only different, but incompatible things, called by the same name-liberty." Lincoln went on to illustrate his point with a parable about animals. "The shepherd drives the wolf from the sheep's throat," he said, "for which the sheep thanks the shepherd as a liberator, while the wolf denounces him for the same act as the destroyer of liberty, especially as the sheep is a black one. Plainly the sheep and the wolf are not agreed upon a definition of the word liberty; and precisely the same difference prevails today among us human creatures, even in the North, and all professing to love liberty. Hence we behold the processes by which thousands are daily passing from under the yoke of bondage, hailed by some as the advance of liberty, and bewailed by others as the destruction of all liberty."

The shepherd in this fable was, of course, Lincoln himself; the black sheep was the slave, and the wolf his owner. As commander in chief of an army of a million men, Lincoln wielded a great deal of power, and by this stage of the war that power was being used not only to defeat the Confederacy and preserve the Union, but also to abolish slavery. But traditionally in American ideology, power was the enemy of liberty. Americans had fought their revolution to get free of the power of the British crown. "There is tendency in all Governments to an augmentation of power at the expense of liberty," wrote James Madison. To curb this tendency, framers of the Constitution devise a series of checks and balances that divided power among three branches of the national government, between two houses of Congress, and between the state and federal governments as, in Madison's words, an "essential precaution in favor of liberty." Even that was not enough; in the first ten 
amendments to the Constitution, the Bill of Rights, the power of the national government was further limited by all the "shall nots" in those amendments. Through most of early American history, those who feared the potential of power to undermine liberty remained eternally vigilant against this threat. When the famous reformer of the treatment of the mentally ill, Dorothea Dix, persuaded Congress to pass a bill granting public lands to the states to subsidize mental hospitals in 1854, President Franklin Pierce vetoed it in the name of preserving liberty. For if Congress could do this, warned Pierce, "it has the same power to provide for the indigent who are not insane, and thus...the whole field of public beneficence is thrown open to the care and culture of the Federal Government." This would mean, continued Pierce's veto message, "all sovereignty vested in an absolute consolidated central power, against which the spirit of liberty has so often and in so many countries struggled in vain." The bill for mental hospitals, therefore, would be "the beginning of the end... of our blessed inheritance of representative liberty." Proslavery Southerners like John C. Calhoun insisted on keeping the national government weak, as insurance against a possible antislavery majority in Congress at some future time that might try to abolish or weaken slavery. State sovereignty, or state's rights, was a bulwark against this potential antislavery majority. The most extreme manifestation of state sovereignty, of course, was secession in the name of the liberty of Southern states and Southern people to reject the federal government and form their own proslavery nation. If this version of liberty was to be used to destroy the United States, concluded most Northerners during the Civil War, then it was time to take another look at the meaning of liberty.

To help us understand this change in attitude toward the meaning of liberty, we can turn to the definitions offered by the famous twentieth-century British philosopher Isaiah Berlin in an essay titled "Two Concepts of Liberty." The idea of negative liberty is perhaps more familiar. It can be defined as the absence of restraint, a freedom from interference by outside authority with individual thought or behavior. Laws requiring automobile passengers to wear seat belts or motorcyclists to wear helmets would be, under this definition, to prevent them from enjoying the liberty to choose not to wear seat belts or helmets. Negative liberty, therefore, can be described as freedom from. Positive liberty, by contrast, can be understood as freedom to. It is not necessarily incompatible with negative liberty-freedom from interference with what a writer 
writes or a reader reads. But an illiterate person suffers from a denial of positive liberty; he is unable to enjoy the freedom to write or read whatever he pleases, not because he cannot read or write anything. He suffers not the absence of a negative liberty-freedom from-but of positive liberty-freedom to read and write. The remedy lies not in removal of restraint but in achievement of the capacity to read and write.

The Civil War accomplished a historic shift in American values in the direction of positive liberty. The change from all those "shall nots" in the first ten amendments to the Constitution to the phrase "Congress shall have the power to enforce this provision" in most of the post-Civil War amendments is indicative of that shiftespecially the Thirteenth Amendment, which liberated four million slaves and the Fourteenth and Fifteenth, which guaranteed them equal civil rights and political rights.

Abraham Lincoln played a crucial role in this historic change toward positive liberty. Let us return to Lincoln's parable of the shepherd, the wolf, and the black sheep. "The shepherd drives the wolf from the sheep's throat, for which the sheep thanks the shepherd as a liberator." Here is Lincoln the shepherd using the power of government and the army to achieve a positive liberty for the sheep. But the wolf was a believer in negative liberty, for to him the shepherd was "the destroyer of liberty, especially as the sheep was a black one."

Positive liberty is an open-ended concept. It has the capacity to expand toward notions of equity, justice, social welfare, equality of opportunity. For how much liberty does a starving person enjoy, except the liberty to starve? How much freedom of the press can exist in a society of illiterate people? How free is a motorcyclist who is paralyzed for life by a head injury that might have been prevented if he had worn a helmet?

With the "new birth of freedom" invoked by Lincoln in the Gettysburg Address, he helped move the nation toward an expanded and open-ended concept of positive liberty. "On the side of the Union," Lincoln said on another occasion, this war "is a struggle for maintain in the world, that form, and substance of government, whose leading objective is, to elevate the condition of men-to lift artificial weights from all shoulders-to clear the paths of laudable pursuit for all, to afford all, an unfettered start, and a fair chance, in the race of life." 
The tension between negative and positive liberty did not come to an end with the Civil War, of course. That tension has remained a constant in American political and social philosophy. In recent years, with the rise of the tea party and other smallgovernment or anti-government movements in our politics, there has been a revival of negative liberty. The presidential election of 2012 pitted the concepts of positive and negative liberty against each other more clearly than in any other recent election. How this tension will play out, in the midst of our sesquicentennial observations of the Civil War, remains to be seen. In any case, it is another example of "Why the Civil War Still Matters." 